\title{
Individual Determinants of Climate Change Scepticism in the Czech Republic ${ }^{1}$
}

\author{
Daniel Čermák ${ }^{2}$ - Věra Patočková ${ }^{3}$ \\ Institute of Sociology, Czech Academy of Sciences, Prague

\begin{abstract}
Individual Determinants of Climate Change Scepticism in the Czech Republic This article focuses on the issue of climate change scepticism among the inhabitants of the Czech Republic and pursues two objectives: to compare climate change scepticism of Czech citizens with citizens of other European countries and to examine the relationship between individual characteristics of Czech citizens and their opinion on climate change. For this purpose, the concepts of epistemic scepticism and response scepticism are employed. The data from round 8 of the European Social Survey are analysed to demonstrate the level of Czech climate change scepticism in comparison with other European countries and to examine the association between the individual characteristics of Czech citizens and climate scepticism. The results indicate that Czech citizens are among the most sceptical in Europe. Furthermore, the outcomes from a series of regression models demonstrate that both epistemic scepticism and response scepticism are associated with political trust and personal values The findings are contrasted to previous research from other European countries and differences are discussed, taking the specific Czech historical, economic and political context into account.

Sociológia 2020, Vol. 52 (No. 6: 578-598)

https://doi.org/10.31577/sociologia.2020.52.6.24
\end{abstract}

Key words: Climate change; climate scepticism; Czech Republic; epistemic scepticism; response scepticism

\section{Introduction}

Although voices hinting at the anthropogenic nature of global climate change began to emerge as early as the late $19^{\text {th }}$ century, it was not until the last two decades of the $20^{\text {th }}$ century that the risks associated with climate change started being perceived as a serious threat (Weart 2010). Anthropogenic climate change made its way into public agendas in the late 1980s (Moser 2010). Urgent warnings of the dire consequences of human-induced climate change have been on the rise ever since (Wuebbles et al. 2017; IPCC 2018). These recently published reports from USGCRP (Wuebbles et al. 2017) and IPCC (2018) studies outline the risks associated with the predicted $1.5^{\circ} \mathrm{C}$ rise in temperature compared to the average increases in the years 1850-1900. This increase is projected to be reached by no later than 2052 (IPCC 2018).

\footnotetext{
1 Acknowledgements: This work was supported by the Czech Science Foundation under Grant GA17-05263S Local response to climate change in the Czech Republic: a sociological perspective.

2 Address: PhDr. Daniel Čermák, Ph.D., The Institute of Sociology of the Czech Academy of Sciences, Jilská 1, 11000 Praha 1, Czech Republic. E-mail: daniel.cermak@soc.cas.cz

3 Address: Mgr. Věra Patočková, M.A. Ph.D., The Institute of Sociology of the Czech Academy of Sciences, Jilská 1, 110 00 Praha 1, Czech Republic. E-mail: vera.patockova@ soc.cas.cz
} 
However, these reports have been appearing alongside sceptical voices that question the existence of climate change or cast doubt on, for instance, the risk climate change poses and the role humans play in it. Czechia is one of the countries with less prevalent environmental concerns and relatively more prevalent climate change scepticism, according to cross-national surveys by the International Social Survey Programme and the Eurobarometer (see Special Eurobarometer 435 2015; Franzen - Vogl 2013). Moreover, ongoing research by the Czech Public Opinion Research Centre shows that the percentage of people who do not consider global climate change as a serious problem grew between 2007 and 2013 (see Vidomus 2013). This topic, i.e. doubt over the existence of climate change in Czechia, is the main focus of our article. Using data from round 8 of the European Social Survey, conducted in 2016 and 2017, we have two primary objectives: to compare the attitudes of Czech citizens towards climate change in comparison with the attitudes of inhabitants of other European countries and to identify the relationship between an individual's characteristics and their opinion on climate change.

\section{Background}

The denial of scientific findings is neither a novel nor undocumented phenomenon (Björnberg et al. 2017). Despite evidence attesting to the severity of human-induced climate change, there are still many laypeople who deny its existence. Scepticism towards climate change has taken many different forms over the last quarter of a century, be it denial of the very existence of climate change, the impact of humans on global climate change, or claims denying the severity of this impact (Dunlap - McCright 2010). Dunlap and McCright (2010) trace the beginnings of this scepticism trend to the conservative era in the USA, spurred by the election of Reagan in 1981, though such discourse was not confined to the USA and slowly expanded to other countries, including those in Europe.

This phenomenon has been addressed by a number of researchers in Europe (see e.g. Poortinga et al. 2011; Whitmarsh 2011; Engels et al. 2013; Capstick Pidgeon 2014). Despite the presence of scepticism towards climate change, we cannot say that Europeans perceive climate change as merely a marginal issue. In the 2017 Eurobarometer survey, climate change was selected by respondents from EU member states as the $3^{\text {rd }}$ most serious problem currently facing the entire world as a whole, after 'poverty, hunger and lack of drinking water' and 'international terrorism' (Special Eurobarometer 459 2017).

Capstick and Pidgeon (2014) conducted their own research, which combined a qualitative and quantitative approach, aimed at gaining deeper insight into climate change scepticism. They identified two main types of climate change scepticism: epistemic scepticism and response scepticism. They define 
epistemic scepticism as follows: 'Our qualitative analysis ... shows that such scepticism relates to perceptions of the legitimacy of climate science claims.' (2014: 397) Such claims cast doubt on the existence of climate change, as well as the human factor purported to be at the root of such change. Such people tend to challenge scientific expertise and reliability. Conversely, response scepticism is described as 'encompassing doubts about the effectiveness of responding to climate change, and concerning the ability and willingness of social actors to respond to it.' (Capstick - Pidgeon 2014: 393) In this case, people tend to question the efficacy of possible responses to climate change on all levels: individual, social, and institutional.

\section{Attitudes to Climate Change and Scepticism in Czechia}

Perception of climate change, its causes and potential consequences is also influenced by factors stemming from the country's specific context. Throughout the 1990s, following the Velvet Revolution of 1989, the debate on climate change was predominantly confined to the scientific sphere (Vidomus 2018). The interest of the Czech media in the topic of climate change was postponed till 1997, however, since then, the trends in Czech media coverage of climate change are akin to those of European and American news outlets (Vávra et al. 2014a). However, since 2007, there has been a trend towards the politicization of the topic. A strong influence was exerted by the Czech president at that time, Václav Klaus, who actively cast doubt on anthropogenic climate change and boosted the subject of climate scepticism to the top of the agenda (Vidomus 2018).

Research results suggest that 'Czechs understand climate change as something rather abstract, distant (and may be also less salient) and do not feel affected by its consequences, unless these are explicitly listed' (Vávra et al. 2014b: 32). More Czechs are willing to provide an affirmative answer when asked whether they believe that the Earth's climate is changing comparing to their responses to the question whether climate change is happening. Krajhanzl et al. (2018) assume that the wording of the question in 'Do you think that the Earth's climate is changing?' does not evoke associations with the terms 'climate change' or 'global warming' (Krajhanzl et al. 2018). Similarly, results from Eurobarometer 2017 indicate that about a half of Czechs do not associate certain actions they engage in with tackling climate change (Special Eurobarometer 459 2017).

Vidomus (2018) also points out that Czechs have long placed greater emphasis on local rather than global issues and that the impact of climate change in the Czechia is less palpable due to the country's location in the temperate climate zone. 
Another specific feature that may lead to underestimation of global change is that the objectives outlined in the Kyoto Protocol were met without any great difficulty in Czechia, mostly due to transformation of the industry and economy, which led to a reduction in pollutant emissions in the early 1990s, and not as a result of deliberate ecological modernization (Kušková 2003; Pavlínek Pickles 2004; Vidomus 2018).

In his qualitative analysis of active climate change scepticism in Czechia, Vidomus (2013) has identified three thematic areas that have been framed as 'uniquely Czech' by the majority of his respondents: 1 . the sceptical nature of the 'ideology resistant population' (historically rooted in the nation's communist past) 2. the role of the most prominent Czech climate sceptic, former president Václav Klaus, and 3. the overlap of climate change and Euroscepticism (Vidomus 2013: 104).

\section{Aims of the study}

In this study, we will focus our efforts to verify the position of Czechia among other European countries in terms of climate scepticism on the European Social Survey (ESS) dataset in the first step. In the second step, we conduct an analysis in order to establish the relationship between climate change scepticism and some of its individual predictors - socio-demographic and other personal characteristics of Czech citizens. We have incorporated the framework created by Capstick and Pidgeon (2014) into our analysis in both steps.

In the second step we tested on an individual level, in addition to further characteristics, Vidomus' finding that climate scepticism is connected with the scepticism and Euroscepticism present in Czech society. The first of these originated in the communist era. 'The profound demoralization of citizens, learned helplessness, undemocratic thinking and distrust of institutions' (Marková Macek 2004: 173) are often referred to as consequences of the communist era in Eastern Europe. This distrust, uncertainty or scepticism has been oriented towards newly established institutions at a time of major social, economic and political changes (Marková - Macek 2004). In Czechia, the communist legacy manifested itself in a lower level of trust in political institutions as well as in lower levels of generalized/interpersonal trust (Sedláčková 2012). Scepticism about democracy could also be manifested as low voter turnout (see e.g. Karp Milazzo 2015).

Czechia is also considered a Eurosceptic country. In 2016, the year to which our analyses relate, $41 \%$ of Czechs agreed with the statement that it could be better to face the future outside the EU ( 9 percentage points over the EU average). Only $31 \%$ tend to trust the European Parliament (the EU average was $42 \%$; only Greece had a lower level of trust at that time) (Standard Eurobarometer 86 2016). According to Kratochvíl and Sychra (2019: 24) 'Czechs are 
not born Eurosceptics - their negative views of the EU are largely the result of the political disconnect between domestic concerns and broader EU-related issues.' The Eurosceptic position is often connected with one of the two dominant political parties in 1993 to 2013, the Civic Democratic Party (ODS $)^{4}$, and also with its chairman $(1991$ - 2002), later the country's president (2003 2013), Václav Klaus (Cabada 2016). It should be pointed out that Václav Klaus is a prominent climate sceptic as well. Such a connection between climate change scepticism and Euroscepticism is not only typical of Czechia, as it has also been identified in other European countries (see Forchtner 2019).

We also control in our study for various socio-demographic and political characteristics based on previous studies on different measures of environmental concern. The relation between environmental concern and the abovementioned characteristics was examined by Van Liere and Dunlap (1980), who based their examination on a review of existing literature. They found that environmental concern is relatively strongly associated with age, education and political ideology. Environmental concern was higher among young, welleducated, and liberal persons than among old, less educated, and conservative ones. The relationship between measures of environmental concern and standard demographic predictors was also scrutinised by Klineberg et al. (1998). They identified reliable relationships with different measures for age and education. 'Younger and better-educated members of the public do indeed appear to be more concerned about issues of environmental quality and to be more committed to environmental protection, almost regardless of the way the dependent variable is measured' (Klineberg et al. 1998: 749). McCright et al. (2016) identified and discussed the most consistent predictors of pro-climate views across 87 studies pooled together in their review essay. Among the predictors investigated, with regard to belief in climate change or concern about climate change the most consistent were pro-environmental values, beliefs or identity. They are followed by political orientation (encompassing political ideology and party identification), with left-oriented voters usually having more pro-climate views. Other characteristics used as significant predictors in studies are post-materialist values, gender, age and education. If they have a statistically significant effect on pro-climate views, women are usually more pro-climate oriented than men, younger people more than older ones, the moreeducated more than the less-educated, and people with post-materialist values are more frequently pro-climate oriented (McCright et al. 2016). We also decided to add one more predictor - parenthood (e.g. presence of children under 15 years old in the household). Parenthood have been tested as control variable in recent studies (e.g. Marshall 2004; McCright - Dunlap 2011). In keeping

${ }^{4}$ The second was the Czech Social Democratic Party (ČSSD). 
with the studies, it is possible to expect that people with children will have greater environmental concern.

A number of studies (e.g. Poortinga et al. 2011; Stern et al. 1998, 1999; De Groot - Steg 2007, 2008; Bouman et al. 2018; Nordlund - Garvill 2002) also tested the effect of values on pro-climate norms, beliefs and behaviour. The values in these studies were measured directly using SVS (Schwartz Value Survey) or Schwarz's PVQ (Portrait Value Questionnaire), or a modified form of these methods was used. When testing values using SVS or PVQ, in a number of differing cultures it was found that values might differ between cultures, but they could nevertheless be categorised into two dimensions (De Groot Steg 2007; Schwartz 2001, 2012). The first dimension is openness to change vs. conservatism, which differentiates between values connected with selfdirection and stimulation on one hand, and on the other those connected with tradition, conformity and security. The second dimension, that of selfenhancement values vs. self-transcendent values, captures the conflict between putting one's own interests first (orientation toward achievement and power) on one hand and putting the interests and welfare of others first (orientation towards universalism and benevolence) on the other hand. This dimension is more suited to our research. 'Research shows that especially the self-transcendent (i.e., altruistic or biospheric) versus self-enhancement (i.e., egoistic) dimension is related to different types of environmental beliefs and behaviours, because environmental behaviour often involves a conflict between immediate individual gains and long-term collective interests'(De Groot - Steg 2007: 319).

\section{Data and measurement/Method}

\section{Design and participants}

In order to conduct a comparison between attitudes to climate change in Czechia and other countries, data were used from an international comparative study, the European Social Survey (ESS) ${ }^{5}$, specifically round 8 which included a module on Public Attitudes to Climate Change and Energy Security. The data were collected between the years 2016 and 2017 from 23, predominantly European, countries. All 44,387 respondents were aged 15 and over, regardless of their nationality, citizenship, language or legal status. We will pay close attention to the situation in Czechia in the following analysis, also employing data from the ESS that were collected in Czechia $(\mathrm{N}=2269)$ towards the end of 2016 (See more in European Social Survey 2017).

\footnotetext{
5 The European Social Survey is a biennial cross-national survey that has been conducted since 2002 using high methodological standards to provide freely available data. Each round contains two modules on key social themes. It uses crosssectional probability samples in each country. More about survey content, data, methodology and sampling can be found at www.europeansocialsurvey.org.
} 


\begin{abstract}
Measures
For our secondary analyses we used data sets from ESS round 8, in which questions were formulated concerning climate change scepticism. Nevertheless, we were limited to predictors contained in the data set. When creating our models, we focused on predictors discussed in the specialist literature, and added to them predictors based on Czech specifics.

In selecting predictors, we took into account three questions: whether they are accessible in the data set, how high their item nonresponse rate is and the distribution of answers to some questions that were influenced by the specific Czech environment. For example, religiosity, ethnicity and income were significant predictors of belief in or concern about climate change in some studies according to McCright et al. (2016). Nevertheless, it would not be advisable to use these predictors in our models, because Czech society is fairly homogenous as far as ethnicity is concerned (97.5\% of the sample are Czech) and also religiosity (only $8 \%$ attend religious services at least once a month and only $18 \%$ belong to a particular religion or denomination). A high item nonresponse rate, on the other hand, is the reason why household income could not be used (28\% were not willing to share information about their household income).
\end{abstract}

\title{
Climate change scepticism
}

We utilized a set of thirteen questions, forming a block of questions on the topic of climate change in ESS round 8, to create an index of epistemic scepticism and an index of response scepticism. All thirteen questions are presented in Table 1, along with the results of an exploratory factor analysis. The following three factors were generated as a result (see Table 1). The results of the factor analysis (PCA) are in large part similar to the results obtained by Capstick and Pidgeon (2014).

The items with the highest factor loadings for the first factor are concentrated primarily in the existence of climate change (trend), the agent(s) of climate change (attribution) and its impact. In terms of the second factor, the highest factor loadings can be observed in items pertaining to the response of ongoing climate change on a 'personal, political and general level,' (see Capstick Pidgeon 2014: 396). Based on the above, we have decided to call the first factor 'epistemic scepticism', and the second, 'response scepticism', in accordance with Capstick and Pidgeon (2014). The third factor can be characterized as the willingness to accept selected climate change mitigation measures.

We also carried out a PCA on the set of respondents from Czechia. The results obtained were comparable to those of the PCA applied to the entire set from all participating countries, revealing that the same questions saturate the same factors. Unfortunately, we discovered that a relatively high number (19\%) of respondents did not respond to at least one of the relevant questions. We 
thus decided to create indices for the epistemic scepticism scale and response scepticism scale, converting all of the used items to a scale from 0 to 10 , where 0 represented no scepticism towards climate change and 10 indicated high scepticism. Each of the indices represents an average of the items depicted. For both indices only some of the originally 13 items analysed were selected. The reason was the need to achieve reasonable reliability of the items forming the indices of epistemic and response scepticism (for more details see table 2). For both indices we tolerated the respondent's failure to respond to one of the items.

Table 1: Results of factor analysis of scepticism items

\begin{tabular}{|c|c|c|c|}
\hline & \multicolumn{3}{|c|}{ Component } \\
\hline & 1 & 2 & 3 \\
\hline $\begin{array}{l}\text { You may have heard the idea that the world's climate is changing due to } \\
\text { increases in temperature over the past } 100 \text { years. What is your opinion on } \\
\text { this? Do you think the world's climate is changing? }\end{array}$ & -0.641 & 0.027 & 0.051 \\
\hline How much have you thought about climate change before today? & 0.706 & 0.094 & -0.076 \\
\hline $\begin{array}{l}\text { Do you think that climate change is caused by natural processes, human } \\
\text { activity, or both? }\end{array}$ & 0.531 & 0.038 & -0.149 \\
\hline $\begin{array}{l}\text { To what extent do you feel personal responsibility to try to reduce climate } \\
\text { change? }\end{array}$ & 0.511 & 0.466 & -0.205 \\
\hline How worried are you about climate change? & 0.752 & 0.195 & -0.104 \\
\hline $\begin{array}{l}\text { How good or bad do you think the impact of climate change will be on } \\
\text { people across the world? }\end{array}$ & -0.574 & 0.267 & 0.131 \\
\hline $\begin{array}{l}\text { Now imagine that large numbers of people limited their energy use. How } \\
\text { likely do you think it is that this would reduce climate change? }\end{array}$ & 0.291 & 0.593 & -0.165 \\
\hline $\begin{array}{l}\text { How likely do you think it is that large numbers of people will actually } \\
\text { limit their energy use to try to reduce climate change? }\end{array}$ & -0.098 & 0.786 & 0.001 \\
\hline $\begin{array}{l}\text { And how likely do you think it is that governments in enough countries } \\
\text { will take action that reduces climate change? }\end{array}$ & -0.142 & 0.692 & -0.001 \\
\hline $\begin{array}{l}\text { How likely do you think it is that limiting your own energy use would help } \\
\text { reduce climate change? }\end{array}$ & 0.158 & 0.733 & -0.110 \\
\hline $\begin{array}{l}\text { To what extent are you in favour or against the following policies in [coun- } \\
\text { try] to reduce climate change? Increasing taxes on fossil fuels, such as oil, } \\
\text { gas and coal. }\end{array}$ & -0.073 & -0.159 & 0.656 \\
\hline $\begin{array}{l}\text { To what extent are you in favour or against the following policies in [coun- } \\
\text { try] to reduce climate change? Using public money to subsidise renewable } \\
\text { energy such as wind and solar power. }\end{array}$ & -0.138 & 0.017 & 0.720 \\
\hline $\begin{array}{l}\text { To what extent are you in favour or against the following policies in [coun- } \\
\text { try] to reduce climate change? A law banning the sale of the least energy } \\
\text { efficient household appliances. }\end{array}$ & -0.155 & -0.058 & 0.671 \\
\hline
\end{tabular}

Source: ESS Round 8 Data (2016) and own calculations. Note: Principal component analysis, varimax rotation, Kaiser-Meyer-Olkin Measure of Sampling Adequacy $=0.817$. 
Table 2: List of variables used for calculating mean indices of climate change scepticism

\begin{tabular}{|c|c|c|}
\hline Items & Czechia & $\begin{array}{l}\text { All participating coun- } \\
\text { tries }\end{array}$ \\
\hline Epistemic Scepticism & $\begin{array}{c}\text { Reliability- } \\
\text { Cronbach's } \alpha=0.69\end{array}$ & $\begin{array}{c}\begin{array}{c}\text { Reliability-Cronbach's } \\
\alpha=0.68\end{array} \\
\end{array}$ \\
\hline Do you think the world's climate is changing?* & Trend scepticism & \\
\hline $\begin{array}{l}\text { How much have you thought about climate change before } \\
\text { today? }\end{array}$ & Climate change salience & \\
\hline $\begin{array}{l}\text { Do you think that climate change is caused by natural pro- } \\
\text { cesses, human activity, or both? }\end{array}$ & Attribution scepticism & \\
\hline How worried are you about climate change? & Impact scepticism & \\
\hline $\begin{array}{l}\text { How good or bad do you think the impact of climate change } \\
\text { will be on people across the world? }\end{array}$ & Impact scepticism & \\
\hline Response Scepticism & $\begin{array}{c}\text { Reliability- } \\
\text { Cronbach's } \alpha=0.71\end{array}$ & $\begin{array}{l}\text { Reliability-Cronbach's } \\
\boldsymbol{\alpha}=\mathbf{0 . 7 1}\end{array}$ \\
\hline $\begin{array}{l}\text { Imagine that large numbers of people limited their energy } \\
\text { use. How likely is it that this would reduce climate change? }\end{array}$ & Response scepticism & \\
\hline $\begin{array}{l}\text { How likely do you think it is that large numbers of people } \\
\text { will actually limit their energy use to try to reduce climate } \\
\text { change? }\end{array}$ & Response scepticism & \\
\hline $\begin{array}{l}\text { How likely do you think it is that governments in enough } \\
\text { countries will take action that reduces climate change? }\end{array}$ & Response scepticism & \\
\hline $\begin{array}{l}\text { How likely do you think it is that limiting your own energy } \\
\text { use would help reduce climate change? }\end{array}$ & Response scepticism & \\
\hline
\end{tabular}

Sociodemographics

The model uses standard socio-demographic predictors as control variables: gender, age, highest level of education, and the presence of children under 15 years old in the household (children in household). Educational attainment is measured on a country-specific 12-point scale from incomplete elementary education to doctoral degree.

\section{Value orientations}

Value orientations were identified using the Portrait Value Questionnaire (PVQ), a 21-item measure developed by Schwarz specifically for European Social Surveys on the base of the original Schwartz Value Survey (see Schwarz 2001). Respondents read short portraits and then indicated how similar the person depicted was to themselves on a 6-point scale. In accordance with the findings discussed in the previous text, in the models we used the dimension self-enhancement values vs. self-transcendent values. 
Table 3: Coding, mean, and standard deviations of predictors in the OLS regression

\begin{tabular}{|c|c|c|c|c|c|}
\hline $\begin{array}{c}\text { Nominal variables (dummy varia- } \\
\text { bles in OLS model) }\end{array}$ & \multicolumn{5}{|c|}{ Values and frequencies } \\
\hline Gender & \multicolumn{5}{|c|}{ 1-Male $(48.8 \%) ; 2$-Female $(51.2 \%)$} \\
\hline $\begin{array}{l}\text { Respondent lives with children under } \\
15 \text { in the household }\end{array}$ & \multicolumn{5}{|c|}{ 0-No $(70.7 \%) ; 1$-Yes $(29.3 \%)$} \\
\hline Voted in last parliamentary elections & \multicolumn{5}{|c|}{1 -Yes $(50.5 \%) ; 2-\operatorname{No}(37.3 \%)$; Other* $(12.2 \%)$} \\
\hline Other variables, including indices & $\begin{array}{l}\text { Reliability } \\
\text { of indices }\end{array}$ & Mean & SD & Min & Max \\
\hline Age & - & 43.08 & 17.13 & 15 years & 92 years \\
\hline Highest level of education & - & 5.61 & 2.59 & 1 -Less 5 years & $\begin{array}{l}\text { 12-PhD or equiva- } \\
\text { lent }\end{array}$ \\
\hline Self-placement on a left-right scale & - & 5.27 & 2.16 & 0-left & 10-right \\
\hline $\begin{array}{l}\text { Should EU unification go further or } \\
\text { has it already gone too far? }\end{array}$ & - & 5.53 & 2.62 & $\begin{array}{l}\text { 0-Unification } \\
\text { should go further }\end{array}$ & $\begin{array}{l}\text { 10-Unification } \\
\text { already gone too } \\
\text { far }\end{array}$ \\
\hline Altruism (self-transcendence) values & 0.76 & 4.36 & 0.77 & 1- Not like me at & 6-Very much like \\
\hline Egoism (self-enhancement) values & 0.77 & 3.88 & 0.93 & all & me \\
\hline Index of generalized social trust & 0.83 & 5.12 & 1.82 & 0-No trust at all & 10-Complete trust \\
\hline \multicolumn{6}{|c|}{$\begin{array}{l}\text { Questions: 1. Can people be trusted, or can you never be too careful?;2. Would most people try to take ad- } \\
\text { vantage of you if they got the chance, or would they try to be fair?; 3. Do people try to be helpful most of the } \\
\text { time, or are they mostly looking out for themselves? }\end{array}$} \\
\hline Index of trust in political institutions & 0.92 & 3.82 & 2.16 & 0-No trust at all & 10-Complete trust \\
\hline
\end{tabular}

Note: * The "Other" category is the sum of the answers "Not eligible to vote; Refusal to answer; Don't know."

Means and standard deviations are for Czech sample $(\mathrm{N}=2269)$. Some indicators were reversely recoded in order to facilitate a better understanding of the calculated models.

\section{Trust and scepticism}

Generalized social trust, political trust and voter turnout (voted in the last parliamentary elections to the lower chamber) were used as predictors of trust and scepticism. For this purpose, we constructed an index of generalized social trust and an index of trust in political institutions. The index of generalized social trust is the average result of three questions regarding generalized social trust, measured on an 11-point scale. Three questions concerning generalized trust are a standard part of the ESS. They were originally employed by Rosenberg (1956), and their applicability was tested by Reeskens and Hooghe (2008).

We constructed the index of trust in political institutions similarly to the generalized social trust. In this case the three questions concerned trust in the Czech parliament, Czech politicians and Czech political parties. An identical 
index based on the ESS dataset was already employed by Fairbrother et al. (2019).

\section{Euroscepticism}

Euroscepticism tends to be connected with attitudes towards deepening European integration and attitudes towards membership of the EU (joining, remaining, leaving). These attitudes may be demonstrated by, for example, voting for Eurosceptic parties, or a lack of trust in European institutions. In the ESS data set the most suitable question to use in order to identify Euroscepticism seemed to be the question concerning the respondent's position on the Idea of EU (unification). The same indicator of Euroscepticism was also employed by many scholars (e.g. Böhmelt - Bove 2020; Rooduijn 2018; Ejrnæs - Jensen 2019).

\section{Political orientation}

The parties currently represented in the lower chamber of parliament do not have salient environmental policies, and in their election manifestos they focused on more traditional topics such as economic stability, taxes, social issues, healthcare and education (Eibl 2014). We are not therefore able to differentiate between political parties with regard to climate scepticism. Consequently, we use a 11-point left-right scale as a measure of political ideology (Selfplacement on left-right scale).

\section{Results}

\section{Attitudes to/Perception of climate change by Czech Citizens in the European Context}

The first step in our series of analyses was to identify the relative position of Czech citizens on climate change in relation to the other countries that participated in ESS round 8. This position was ascertained using created indices of epistemic scepticism and response scepticism.

Figure 1 displays the average position of respondents from each of the countries on two axes. The horizontal axis presents the country's position in terms of epistemic scepticism, while the vertical axis represents response scepticism. While the group of least sceptical countries is relatively heterogeneous, the group of climate change sceptics paints a coherent picture. We can thus identify a group of countries whose inhabitants are relatively sceptical with respect to both axes: Czechia, Estonia, and Russia, all of which are examples of postcommunist countries in Central and Eastern Europe. If we consider countries that are relatively sceptical only on one of the axes, then we find Slovenia and Germany (former East and West separately analysed) on the response scepticism axis and Israel, Lithuania and Poland on the epistemic scepticism axis. 
Figure 1: PCA Results - distribution of countries according to their average factor scores for all respondents in the given country, epistemic scepticism vs. response scepticism

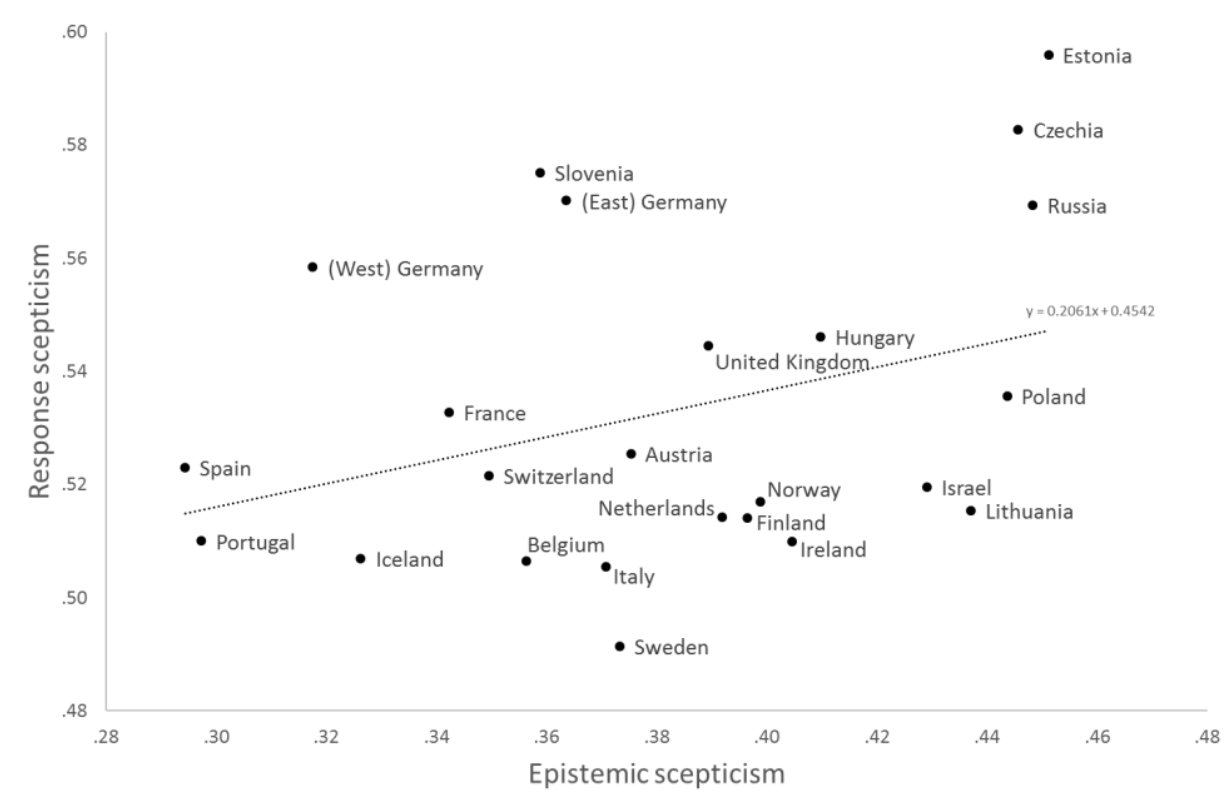

Source: ESS Round 8 Data (2016) and own calculations.

The first step of our analysis involved identifying Czechia as one of the most sceptical countries. Our next task was to identify the determinants of Czech climate change scepticism on an individual level.

\section{OLS regression models}

To ascertain the effects of the predictors analysed on epistemic scepticism and response scepticism we created two sets of OLS regression models. In each set we gradually created three regression models. The first contained only sociodemographic predictors, in the second we added values as predictors and in the third model we included all the predictors analysed.

Of the socio-demographic variables, those where a significant influence was confirmed were gender, education and parenthood. In keeping with most previous studies, men were more sceptical, as were people without children, while epistemic scepticism fell with a growing level of educational attainment. The study also confirmed the supposition that there is a strong correlation between self-transcendence values and epistemic scepticism: people who hold these values are significantly less sceptical. 
Table 4: OLS regression models predicting epistemic climate change scepticism

\begin{tabular}{|c|c|c|c|c|c|c|c|c|c|}
\hline & B & SE & $\mathbf{p}$ & B & SE & $\mathbf{p}$ & B & SE & $\mathbf{p}$ \\
\hline Gender & -0.217 & 0.076 & $* *$ & -0.114 & 0.074 & n.s. & -0.167 & 0.073 & $*$ \\
\hline Age & 0.001 & 0.002 & n.s. & 0.001 & 0.002 & n.s. & 0.004 & 0.003 & n.s. \\
\hline $\begin{array}{l}\text { Children in } \\
\text { household }\end{array}$ & -0.214 & 0.082 & $* *$ & -0.146 & 0.080 & n.s. & -0.171 & 0.080 & $*$ \\
\hline $\begin{array}{l}\text { Highest level } \\
\text { of education }\end{array}$ & -0.087 & 0.015 & $* * *$ & -0.076 & 0.014 & $* * *$ & -0.072 & 0.015 & $* * *$ \\
\hline $\begin{array}{l}\text { Self-enhancement } \\
\text { values }\end{array}$ & & & & 0.011 & 0.045 & n.s. & -0.041 & 0.045 & n.s. \\
\hline $\begin{array}{l}\text { Self- } \\
\text { transcendence } \\
\text { values }\end{array}$ & & & & -0.568 & 0.052 & $* * *$ & -0.526 & 0.051 & $* * *$ \\
\hline $\begin{array}{l}\text { Index of general- } \\
\text { ized soc. trust }\end{array}$ & & & & & & & 0.064 & 0.023 & $* *$ \\
\hline $\begin{array}{l}\text { Index of political } \\
\text { trust }\end{array}$ & & & & & & & 0.115 & 0.020 & $* * *$ \\
\hline $\begin{array}{l}\text { Idea of EU (unifi- } \\
\text { cation) }\end{array}$ & & & & & & & 0.002 & 0.015 & n.s. \\
\hline $\begin{array}{l}\text { Placement on left- } \\
\text { right scale }\end{array}$ & & & & & & & 0.043 & 0.018 & $*$ \\
\hline $\begin{array}{l}\text { Vote in last parl. } \\
\text { elections: Oth- } \\
\text { erVote }\end{array}$ & & & & & & & 0.020 & 0.163 & n.s. \\
\hline $\begin{array}{l}\text { Vote in last parl. } \\
\text { elections: No }\end{array}$ & & & & & & & 0.380 & 0.082 & $* * *$ \\
\hline
\end{tabular}

Note: $* \mathrm{p}<.05$ (two-tailed test). ${ }^{*} \mathrm{p}<.01$ (two-tailed test). ${ }^{*} * \mathrm{p}<.001$ (two-tailed test).

Increasing trust, above all in political institutions, is connected with increasing epistemic scepticism. A possible reason for this may be the fact that most of the Czech political scene in 2016 did not emphasise climate change, preferring other themes.

The scepticism shown by people in not taking part in parliamentary elections is reflected in epistemic scepticism. On the contrary, the predictor indicating Euroscepticism was not significant in the model. Also, only a very weak correlation with political ideology was identified, with epistemic scepticism growing the further right one moves on the left-right scale.

In the case of response scepticism, only a weak correlation with sociodemographic variables was found. As in the previous case, men were moderately more sceptical. In the case of educational attainment, however, there is a relatively weak positive correlation between educational level and the degree of response scepticism. There is, however, a significant correlation between response scepticism and values held. People holding self-transcendence values 
tend to be significantly more sceptical, and people holding self-enhancement values significantly less sceptical.

Table 5: OLS regression models predicting response climate change scepticism

\begin{tabular}{|c|c|c|c|c|c|c|c|c|c|}
\hline & B & SE & $\mathbf{p}$ & B & SE & $\mathbf{p}$ & B & SE & $\mathbf{p}$ \\
\hline Gender & -.121 & .079 & n.s. & -.188 & .079 & $*$ & -.157 & .078 & $*$ \\
\hline Age & .001 & .002 & n.s. & -.003 & .002 & n.s. & -.002 & .003 & n.s. \\
\hline Children in household & -.019 & .086 & n.s. & -.054 & .085 & n.s. & .003 & .085 & n.s. \\
\hline Highest level of education & .008 & .015 & n.s. & .021 & .015 & n.s. & .033 & .016 & $*$ \\
\hline Self-enhancement values & & & & -.260 & .048 & $* * *$ & -.205 & .048 & $* * *$ \\
\hline Self-transcendence values & & & & .182 & .055 & $* * *$ & .141 & .055 & $*$ \\
\hline $\begin{array}{l}\text { Index of generalized soc. } \\
\text { trust }\end{array}$ & & & & & & & -.013 & .024 & n.s. \\
\hline Index of political trust & & & & & & & -.104 & .021 & $* * *$ \\
\hline Idea of EU (unification) & & & & & & & .075 & .016 & $* * *$ \\
\hline $\begin{array}{l}\text { Placement on left-right } \\
\text { scale }\end{array}$ & & & & & & & .001 & .019 & n.s. \\
\hline Vote in last parl. elections: & OtherVote & & & & & & .413 & .174 & $*$ \\
\hline Vote in last parl. elections: & No & & & & & & -.072 & .088 & n.s. \\
\hline
\end{tabular}

Note: $* \mathrm{p}<.05$ (two-tailed test). $* * \mathrm{p}<.01$ (two-tailed test). $* * * \mathrm{p}<.001$ (two-tailed test).

In this model we also find a significant correlation between trust in political institutions and response scepticism, which falls with growing trust. The influence of Euroscepticism proved significant, with those inclining towards the opinion that 'the idea of the EU has gone too far' being at the same time significantly greater response sceptics.

\section{Discussion}

Czechia, together with several other post-communist countries, is one of the most sceptical countries in Europe. Its climate change policy is considered weak and focused mainly on compliance with minimum environmental standards required by the EU (Fagin - Jehlička 1998; Pavlínek - Pickles 2004; Wagner et al. 2020).); this situation is also reflected by the Climate Change Performance Index 2020, in which Czechia ranks 43rd and belongs to the low performance category (Burck et al. 2019).

Cross-national differences can be explained to a substantial degree by differences in population characteristics across countries. Nevertheless, according to specialist literature, several country-level characteristics also affect crossnational differences. Climate impacts, such as repeated experiences of extreme weather events (prolonged periods of abnormally warm or cold temperatures, 
droughts, and floods), contribute to a country's perceived vulnerability to climate change (Deryugina 2013; Spence et al. 2011; Zhou 2015). Another significant factor is the media coverage of climate change and 'the role of elite cues and public expressions of opinions regarding climate change in political discourse', all of which directly affect the level of public concern (Carmichael Brulle 2017: 232-233.).

In addition, some research studies have already focused on explaining differences among countries from the ESS round 8 based on their stance on environmental issues (Fritz - Koch 2019; Otto - Gugashvili 2020). They concluded that setting climate policies is difficult in Czechia, Estonia, Israel, Lithuania, Poland, and Russia because they largely depend on fossil fuel energy and on the jobs the fossil fuel industry produces. Consequently, they show a strong preference for fossil fuels over renewable energy. On the other hand, it is easier to convince people in countries with developed renewable energy production to invest further in renewable sources and other pro-climate measures.

Despite the high scepticism in Czechia, it cannot be said of the sceptical part of the population that they are uniform sceptics, refusing everything to do with climate change and also being sceptical towards the government and the European Union. Who, then, are the Czech climate change sceptics? Our analyses showed that climate change scepticism is not a single universal attitude, and that there are characteristics typical of people who are not sceptical in terms of epistemic scepticism, but are fairly sceptical in terms of response scepticism, and vice versa. This is true above all in the case of trust in political institutions and of people who hold self-transcendent values. To a limited extent, it is also true in the case of educational attainment.

The results also reveal that people who trust political institutions in Czechia more often display epistemic scepticism but less often response scepticism. A likely reason is that if people trust politicians, they are more confident that politicians can deal with environmental problems and their consequences (Zhou 2015).

We have found only a weak association between political ideology (placement on the left-right scale) and epistemic scepticism, and none between political ideology and response scepticism. These findings are in accordance with those of McCright et al. (2015), who found that in Western democracies, leftoriented citizens reported a stronger belief in climate change than right-oriented citizens. On the other hand, they did not find such a political divide in postcommunist countries (McCright et al. 2015; Smith - Mayer 2019). McCright et al. (2015) ascribed this finding to a different understanding of left-right identification and the low political salience of issues connected with climate change in these countries. 
In explaining climate change scepticism, a role is played by scepticism concerning political behaviour, measured by (not) taking part in elections to the lower house of parliament, and by Euroscepticism, measured by attitude to European unification. People who demonstrated their scepticism towards domestic political activity by not taking part in elections were also significantly more likely to display epistemic scepticism. On the contrary, the less people were sceptical towards the idea of EU unification, the less likely they were to be response sceptics. It is as if they believed that the EU guaranteed at least an attempt to resolve climate problems.

In keeping with our expectations, the values held by respondents make themselves felt when explaining epistemic scepticism. Self-transcendence values, indicating that the holders prioritize the interests of others or the public welfare, are held to a greater extent by respondents who are not epistemic sceptics, but who are moderate response sceptics. They are aware of the existence, causes and effects of climate change, but they are to a certain extent sceptical as to how much of a will exists to deal with them.

On the contrary, those oriented towards self-enhancement values, in other words people who put their interests ahead of the interests of others and are oriented towards achieving results, show trust in the solution of problems connected with climate change; in other words, they show a low degree of response scepticism.

The research presented here has shown us what characteristics are associated with people who are more frequently sceptical, and that there is a need to distinguish between them with regard to what type of scepticism they display, epistemic or response scepticism. It is clear that the people who display each type of scepticism are usually not identical.

It should be mentioned that Czech climate change awareness was higher in 2019 than in both 2017 and 2015 (Special Eurobarometer 435 2015; Special Eurobarometer 490 2019), i.e. the years when the Czech ESS dataset was collected. According to the Eurobarometer 490 (2019), Czechia follows the general trend of growing climate change awareness in the European Union; nevertheless, Czechia remains in the first quartile of the most sceptical countries in terms of the perceived seriousness of the effects of climate change.

The European Green Deal, which was announced by the European Commission President Ursula von der Leyen in December 2019, is a significant stimulus for the further economic and social development of the EU. Additionally, it sets a new direction for our future research on environmental issues in Czechia. We would like to focus on the role of political parties in Czechia and how their policies reflect the European Green Deal. As the elections for the lower chamber of Czech parliament will be held in 2021, the ensuing election manifestos 
and campaigns will be a convenient source of information on parties' stances towards climate change, notably the importance they attribute to it.

Daniel Čermák is working as a researcher at the Institute of Sociology, Czech Academy of Sciences. He earned his PhD at the Charles University with a thesis about trust in political instituions in Czechia. He works in the fields of local and regional studies, political elites and political participation.

Daniel Čermák ORCID iD https://orcid.org/0000-0001-6118-2168

V̌rra Patočková is working as a researcher at the Institute of Sociology, Czech Academy of Sciences. She earned her PhD at the Charles University. Her main research interests include topics such as leisure, culture in local and regional settings, and public governance on local and regional levels.

Věra Patočková ORCID iD https://orcid.org/0000-0001-8813-6110

\section{REFERENCES}

BJÖRNBERG, K. E. - KARLSSONA, M. - GILEK, M. - HANSSON, S. O., 2017: Climate and Environmental Science Denial: A Review of the Scientific Literature Published in 1990 - 2015. Journal of Cleaner Production 167: 229-241. https://doi.org/10.1016/j.jclepro.2017.08.066

BÖHMELT, T. - BOVE, V., 2020: Regional Integration Support: A Positive Externality toward Migration Attitudes. JCMS: Journal of Common Market Studies 58: 309327. https://doi.org/10.1111/jcms.12916

BOUMAN, T. - STEG, L. - KIERS, H., 2018: Measuring Values in Environmental Research: A Test of an Environmental Portrait Value Questionnaire. Frontiers in psychology 9: 564. https://doi.org/10.3389/fpsyg.2018.00564

BURCK, J. - HAGEN, U. - HÖHNE, N. - NASCIMENTO, L. - BALS, C., 2019: Climate Change Performance Index. Results 2020. Berlin and Beirut: Germanwatch, New Climate Institute and Climate Action Network. https://germanwatch.org/sites/germanwatch.org/files/CCPI-2020-Results_1.pdf

CABADA, L., 2016: Party of Free Citizens and the Genesis of the Czech LiberalConservative "Anti-EU" Stream in Czech Politics. Politické vedy 19(2): 8-34.

CAPSTICK, S. B. - PIDGEON, N. F., 2014: What is Climate Change Scepticism? Examination of the Concept Using a Mixed Methods Study of the UK Public. Global Environmental Change 24: 389-401. https://doi.org/10.1016/j.gloenvcha.2013.08.012

CARMICHAEL, J. T. - BRULLE, R. J., 2017: Elite Cues, Media Coverage, and Public Concern: An Integrated Path Analysis of Public Opinion on Climate Change, 2001 - 2013. Environmental Politics 26(2): 232-252. http://dx.doi.org/10.1080/09644016.2016.1263433

DE GROOT, J. - STEG, L., 2007: Value Orientations and Environmental Beliefs in Five Countries: Validity of an Instrument to Measure Egoistic, Altruistic and Biospheric Value Orientations. Journal of Cross-Cultural Psychology 38(3): 318-332. http://dx.doi.org/10.1177/0022022107300278 
DE GROOT, J. - STEG, L., 2008: Value Orientations to Explain Beliefs Related to Environmental Significant Behavior: How to Measure Egoistic, Altruistic, and Biospheric Value Orientations. Environment and Behavior 40(3): 330-354. https://doi.org/10.1177/0013916506297831

DERYUGINA, T., 2013: How do People Update? The Effects of Local Weather Fluctuations on Beliefs about Global Warming. Climatic Change 118(2): 397-416. https://doi.org/10.1007/s10584-012-0615-1

DUNLAP, R. E. - MCCRIGHT, A. M., 2010: Climate Change Denial: Sources, Actors and Strategies. In: Lever-Tracy, C. (ed.): Routledge Handbook of Climate Change and Society. New York: Routledge, pp. 240-259.

EIBL, O., 2014: Analýza volebních programů. In: Gregor, M., Havlík, V., Eibl, O., Gregor, K. (eds.): Volby do Poslanecké sněmovny 2013. Brno: Munipress, pp. 23 54.

EJRNÆS, A. - JENSEN, M. D., 2019: Divided but United: Explaining Nested Public Support for European Integration. West European Politics 42(7): 1390-1419. https://doi.org/10.1080/01402382.2019.1577632

ENGELS, A. - HÜTHER, O. - SCHÄFER, M. - HELD, H., 2013: Public ClimateChange Skepticism, Energy Preferences and Political Participation. Global environmental change 23(5): 1018-1027. https://doi.org/10.1016/j.gloenvcha.2013.05.008

EUROPEAN SOCIAL SURVEY, 2017: ESS Round 8 (2016/2017) Technical Report. London: ESS ERIC. https://www.europeansocialsurvey.org/docs/round8/survey/ ESS8_data_documentation_report_e02_1.pdf

FAGIN, A. - JEHLIČKA, P., 1998: Sustainable development in the Czech Republic: a doomed process? Environmental Politics 7(1): 113-128. https://doi.org/10.1080/09644019808414375

FAIRBROTHER, M. - SEVÄ, I. - KULIN, J., 2019: Political Trust and the Relationship between Climate Change Beliefs and Support for Fossil Fuel Taxes: Evidence from a Survey of 23 European Countries. Global Environmental Change 59: 102003. https://doi.org/10.1016/j.gloenvcha.2019.102003

FORCHTNER, B., 2019: Climate Change and the Far Right. WIREs: Climate Change 10(5): e604. https://doi.org/10.1002/wcc.604

FRANZEN, A. - VOGL, D., 2013: Two Decades of Measuring Environmental Attitudes: A Comparative Analysis of 33 Countries. Global Environmental Change 23(5): 1001-1008. https://doi.org/10.1016/j.gloenvcha.2013.03.009

FRITZ, M., - KOCH, M., 2019: Public Support for Sustainable Welfare Compared: Links between Attitudes Towards Climate and Welfare Policies. Sustainability 11(15): 4146. https://doi.org/10.3390/su11154146

IPCC, 2018: Summary for Policymakers. In: Masson-Delmotte V., Zhai P., Pörtner H. O., Roberts D., Skea J., Shukla P. R., Pirani A., Moufouma-Okia W., Péan C., Pidcock R., Connors S., Matthews J.B.R., Chen Y., Zhou X., Gomis M. I., Lonnoy E., Maycock T., Tignor M., Waterfield T. (eds.): Global Warming of $1.5^{\circ} \mathrm{C}$. An IPCC Special Report on the Impacts of Global Warming of $1.5^{\circ} \mathrm{C}$ above Pre-industrial Levels and Related Global Greenhouse Gas Emission Pathways, in the Context of Strengthening the Global Response to the Threat of Climate Change, Sustainable 
Development, and Efforts to Eradicate Poverty. Geneva: World Meteorological Organization, $32 \mathrm{p}$.

KARP, J. A. - MILAZZO, C., 2015: Democratic Scepticism and Political Participation in Europe. Journal of Elections, Public Opinion and Parties 25(1): 97-110. https://doi.org/10.1080/17457289.2014.996157

KLINEBERG, S. L. - MCKEEVER, M. - ROTHENBACH, B., 1998: Demographic Predictors of Environmental Concern: It does Make a Difference how it's Measured. Social science quarterly 79(4): 734-753.

KRAJHANZL, J. - CHABADA T. - SVOBODOVÁ, R., 2018: Vztah české veřejnosti $\mathrm{k}$ přírodě a životnímu prostředí. Reprezentativní studie veřejného mínění. Brno: Masarykova univerzita. https://munispace.muni.cz/library/catalog/book/1001.

KRATOCHVÍL, P. - SYCHRA, Z., 2019: Czech Republic: A Paradise for Eurosceptics? In: Kaeding M., Pollak J., Schmidt P. (eds): The Future of Europe. Cham: Palgrave Macmillan, pp. 21-24. https://doi.org/10.1007/978-3-319-93046-6_6

KUŠKOVÁ, P. (ed.), 2003: Česká republika 2003: Deset let udržitelného rozvoje? Praha: Centrum pro otázky životního prostředí, Univerzita Karlova.

LIERE, K. D. V. - DUNLAP, R. E., 1980: The Social Bases of Environmental Concern: A Review of Hypotheses, Explanations and Empirical Evidence. Public opinion quarterly 44(2): 181-197.

MARKOVÁ, I. - MACEK, P., 2004: Trust and Distrust in Old and New Democracies. In: Marková, I. (ed.): Trust and Democratic Transition in Post-Communist Europe. Oxford, New York: Oxford University Press, pp. 173-193.

MARSHALL, B. K., 2004: Gender, Race, and Perceived Environmental Risk: The "White Male" Effect in Cancer Alley, LA. Sociological Spectrum 24(4): 453-478. https://doi.org/10.1080/02732170490459485

MCCRIGHT, A. M. - DUNLAP, R. E., 2011: Cool Dudes: The Denial of Climate Change Among Conservative White Males in the United States. Global environmental change 21(4): 1163-1172. https://doi.org/10.1016/j.gloenvcha.2011.06.003

MCCRIGHT, A. M. - MARQUART-PYATT, S. T. - SHWOM, R. L. - BRECHIN, S. R. - ALLEN, S., 2016: Ideology, Capitalism, and Climate: Explaining Public Views about Climate Change in the United States. Energy Research \& Social Science 21: 180-189. https://doi.org/10.1016/j.erss.2016.08.003

MCCRIGHT, A. M. - DUNLAP, R. E. - MARQUART-PYATT, S. T., 2015: Political Ideology and Views about Climate Change in the European Union. Environmental Politics 25(2): 338-358. https://doi.org/10.1080/09644016.2015.1090371

MOSER, S. C., 2010: Communicating Climate Change: History, Challenges, Process and Future Directions. Wiley Interdisciplinary Reviews: Climate Change 1(1): 31 53. https://doi.org/10.1002/wcc.11

NORDLUND, A. M. - GARVILL, J., 2002: Value Structures Behind Proenvironmental Behavior. Environment and behavior 34(6): 740-756. https://doi.org/10.1177/001391602237244

OTTO, A. - GUGUSHVILI, D., 2020: Eco-Social Divides in Europe: Public Attitudes towards Welfare and Climate Change Policies. Sustainability 12(1): 404. https://doi.org/10.3390/su12010404 
PAVLÍNEK, P. - PICKLES, J., 2004: Environmental Pasts/Environmental Futures in Post-Socialist Europe. Environmental Politics 13(1): 237-265. https://doi.org/10.1080/09644010410001685227

POORTINGA, W. - SPENCE, A. - WHITMARSH, L. - CAPSTICK, S. - PIDGEON, N. F., 2011: Uncertain Climate: An Investigation Into Public Scepticism about Anthropogenic Climate Change. Global environmental change 21(3): 1015-1024. https://doi.org/10.1016/j.gloenvcha.2011.03.001

REESKENS, T. - HOOGHE, M., 2008: Cross-Cultural Measurement Equivalence of Generalized Trust. Evidence from the European Social Survey (2002 and 2004). Social Indicators Research 85(3): 515-532. https://doi.org/10.1007/s11205-0079100-z

ROODUIJN, M., 2018: What Unites the Voter Bases of Populist Parties? Comparing the Electorates of 15 Populist Parties. European Political Science Review 10(3): 351-368. https://doi.org/10.1017/S1755773917000145

ROSENBERG, M., 1956: Misanthropy and Political Ideology. American sociological review 21(6): 690-695. https://doi.org/10.2307/2088419

SCHWARTZ, S. H., 2001: Chapter 7: A Proposal for Measuring Value Orientation Across Nations. In: ESS central co-ordinating team. The European social survey core questionnaire development, pp. 259-319. http://www.europeansocialsurvey. org/docs/methodology/core_ess_questionnaire/ESS_core_questionnaire_human_val ues.pdf

SCHWARTZ, S. H., 2012: An Overview of the Schwartz Theory of Basic Values. Online readings in Psychology and Culture 2(1): 2307-0919. https://doi.org/10.9707/2307-0919.1116

SEDLÁČKOVÁ, M., 2012: Důvěra a demokracie. Praha: Sociologické nakladatelství.

SMITH, E. K. - MAYER, A., 2019: Anomalous Anglophones? Contours of free market ideology, political polarization, and climate change attitudes in Englishspeaking countries, Western European and post-Communist states. Climatic Change 152(1): 17-34. https://doi.org/10.1007/s10584-018-2332-x

SPECIAL EUROBAROMETER 435, 2015: Climate Change. https://ec.europa.eu/ clima/sites/clima/files/support/docs/report_2015_en.pdf

SPECIAL EUROBAROMETER 459, 2017: Climate Change. https://ec.europa.eu/com frontof-

fice/publicopinion/index.cfm/Survey/getSurveyDetail/instruments/SPECIAL/surveyKy/ 2140

SPECIAL EUROBAROMETER 490, 2019: Climate Change. https://ec.europa.eu /commfrontoffice/publicopinion/index.cfm/Survey/getSurveyDetail/instruments/SPECI AL/yearFrom/1974/yearTo/2019/surveyKy/2212

SPENCE, A. - POORTINGA, W. - BUTLER, C. - PIDGEON, N. F., 2011: Perceptions of Climate Change and Willingness to Save Energy Related to Flood Experience. Nature climate change 1(1): 46-49. ttps://doi.org/10.1038/nclimate1059

STANDARD EUROBAROMETER 86, 2016: Wave 86.2. https://ec.europa.eu/comm frontof-

fice/publicopinion/index.cfm/Survey/getSurveyDetail/instruments/STANDARD/yearFr om/2015/yearTo/2017/surveyKy/2137 
STERN, P. C. - DIETZ, T. - ABEL, T. - GUAGNANO, G. A. - KALOF, L., 1999: A Value-Belief-Norm Theory of Support for Social Movements: The Case of Environmentalism. Human ecology review 6(2): 81-97.

STERN, P. C. - DIETZ, T. - GUAGNANO, G. A., 1998: A Brief Inventory of Values. Educational and psychological measurement 58(6): 984-1001. https://doi.org/10.1177/0013164498058006008

VÁVRA, J. - LAPKA, M. - DVOŘÁKOVÁ-LÍŠKOVÁ, Z. - CUDLÍNOVÁ, E., 2014a: Obraz změn klimatu v českých denících v letech 1997 - 2010. Naše společná přítomnost II. Praha: Karolinum: 9-33.

VÁVRA, J. - PETERS, V. - LAPKA, M. - CUDLÍNOVÁ, E., 2014b: Social Perception of Climate Change Consequences in the Czech Republic and Germany. In: Duží, B. et al.: Environmental change: Adaptation Challenges. Brno: Global Change Research Centre AS CR, Brno, pp. 21-35.

VIDOMUS, P., 2013: Česká klimaskepse. Úvod do studia. Sociální studia/Social Studies 10(1): 95-127. https://doi.org/10.5817/SOC2013-1-95

VIDOMUS, P., 2018: Oteplí se a bude líp: česká klimaskepse v čase globálních rizik. Praha: Sociologické nakladatelství.

WAGNER, P. M. - YLÄ-ANTTILA, T. - GRONOW, A. - OCELÍK, P. - SCHMIDT, L. DELICADO, A., 2020: Information Exchange Networks at the Climate Science-Policy Interface: Evidence from the Czech Republic, Finland, Ireland, and Portugal. Governance: 1 -18. https://doi.org/10.1111/gove.12484

WEART, S. R., 2010: The Idea of Anthropogenic Global Climate Change in the 20th Century. Wiley Interdisciplinary Reviews: Climate Change 1(1): 67-81. https://doi.org/10.1002/wcc.6

WHITMARSH, L., 2011: Scepticism and Uncertainty about Climate Change: Dimensions, Determinants and Change Over Time. Global environmental change 21(2): 690-700. https://doi.org/10.1016/j.gloenvcha.2011.01.016

WUEBBLES, D. J. - FAHEY, D. W. - HIBBARD, K. A., 2017: Climate Science Special Report: Fourth National Climate Assessment, Volume I. U.S. Washington: Global Change Research Program. http://doi.org/10.7930/J0J964J6

ZHOU, M., 2015: Public Environmental Skepticism: A Cross-National and Multilevel Analysis. International Sociology 30(1): 61-85.

https://doi.org/10.1177/0268580914558285 